\title{
Over 130 years of survival by a small, isolated population of Favia gravida corals at Ascension Island (South Atlantic)
}
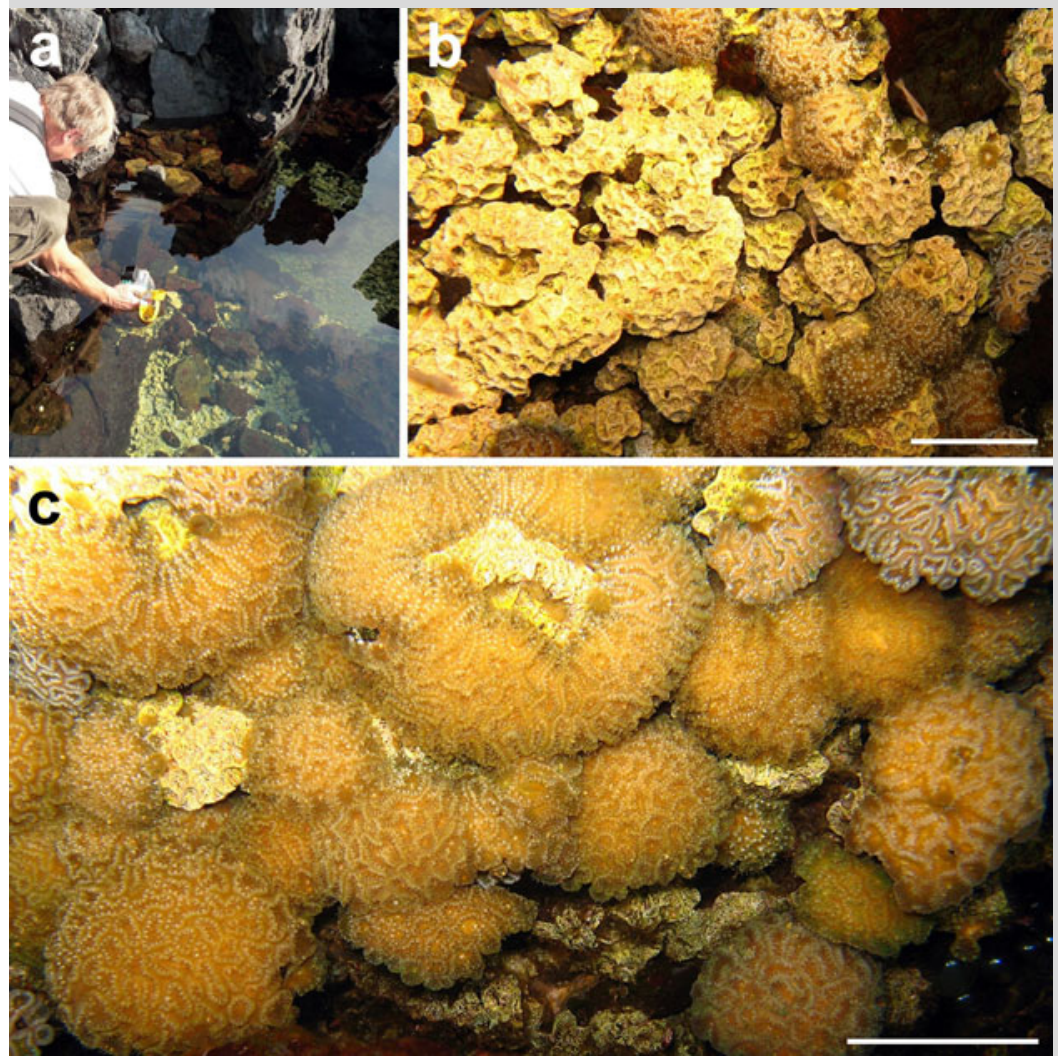

Fig. 1 Favia gravida in a tidal pool on Ascension Island. a Overview showing dead and live corals at bottom. b Close-up of mostly dead corals. c Live specimens in situ. Scale bars: $5 \mathrm{~cm}$
The brooding reef coral Favia gravida (Verrill 1868) has an amphi-Atlantic geographic distribution with a restricted gene flow among populations (Nunes et al. 2011). It occurs on the mid-Atlantic volcanic islands of Ascension and St. Helena, which lie ca. 1,300 km apart from each other. Ascension's shore contains some tidal rock pools of varying depths with small beds of $F$. gravida, which has been recorded from here since 1881 (Hoeksema 2012). The 1881 specimen is a massive coral, described as holotype of Platygyra ascensionis Ridley, 1881, synonym of F. gravida. Specimens collected from 1971 to 1989 consist mainly of free-living, regenerating fragments and some massive attached corals (Hoeksema 2012). Published photographs and descriptions of the corals in situ (e.g., Price and John 1980) have so far not been clear enough to illustrate their unusual free mode of life, which was recently also observed in an isolated population of the scleractinian Madracis decactis (Lyman 1859) (see Capel et al. 2012).

On September 7, 2012, the second author took pictures of $F$. gravida corals on the bottom of the easternmost of the so-called Procaris ascensionis pools at Ascension's Shelly Beach ( $07^{\circ} 59.510 \mathrm{~S}$ $014^{\circ} 23.695 \mathrm{~W}$ ) to verify that the corals were still present (Fig. 1). Since many were dead (Fig. 1b), it is remarkable that Ascension's small population has survived for at least 130 years. It may have maintained itself by inbreeding (see Nunes et al. 2011) and fragmentation, allowing it to adopt a predominantly free mode of life on the rock pool bottoms.

Acknowledgments We are grateful to the assistance given by the Shallow Marine Surveys Group, the South Atlantic Environmental Research Institute, the Darwin Initiative Challenge Fund Grant (EIDCF012), and Stedson Stroud of the Ascension Conservation Department. Ms. Miranda Lowe (Natural History Museum, London) sent the holotype of P. ascensionis (BMNH 1884.4.29.1) on loan. Figure 1a photograph is from F.C. Küpper, University of Aberdeen.

\section{References}

Capel KCC, Segal B, Bertuol P, Lindner A (2012) Corallith beds at the edge of the tropical South Atlantic. Coral Reefs 31:75

Hoeksema BW (2012) Extreme morphological plasticity enables a free mode of life in Favia gravida at Ascension Island (South Atlantic). Mar Biodivers 42:289-295

Nunes FLD, Norris RD, Knowlton N (2011) Long distance dispersal and connectivity in amphi-Atlantic corals at regional and basin scales. PLoS ONE 6:e22298

Price H, John DM (1980) Ascension Island, south Atlantic: a survey of inshore benthic macroorganisms, communities and interactions. Aquat Bot 9:251-278

B. W. Hoeksema $(\square)$

Department of Marine Zoology, Naturalis Biodiversity Center, P.O. Box 9517, 2300 RA Leiden, The Netherlands

e-mail: bert.hoeksema@naturalis.nl

P. Wirtz

Centro de Ciências do Mar, Universidade do Algarve, Campus de Gambelas, 8005-139 Faro, Portugal

Received: 3 October 2012/Accepted: 14 December 2012/Published online: 30 December 2012

Coral Reefs (2013) 32:551

(C) Springer-Verlag Berlin Heidelberg 2012

DOI $10.1007 / \mathrm{s} 00338-012-1002-0$ 